\title{
Saving the Kakapo: the conservation of the world's most peculiar parrot
}

\author{
MICK N. CLOUT and DON V. MERTON
}

\section{Summary}

We review the conservation history and describe the current status of the Kakapo Strigops habroptilus, a large New Zealand parrot which has been reduced to only 54 individuals through predation by introduced mammals, and is now threatened with extinction. Unique amongst parrots, Kakapo are both flightless and nocturnal. They have an unusual mating system in which females nest and raise their young unaided by males, after mating at traditional "courts" at which males display visually and vocally. Mating occurs naturally only in seasons of heavy fruiting of podocarp trees. A decline in range and abundance of Kakapo followed the introduction of alien mammals last century, and culminated in their reduction to a single breeding population on Stewart Island. Following a severe episode of predation by feral cats Felis catus, all known birds from this last population were translocated to a series of cat-free offshore islands. Adult survival on these island sanctuaries has been high (c. $98 \%$ per annum), but productivity has been low, with only six young (including a single female) raised to independence since 1982 . Reasons for this low productivity are the naturally intermittent breeding of Kakapo, the low numbers of nesting females, high rates of egg infertility $(\sim 40 \%)$, and the early death of most nestlings through starvation or suspected predation by Polynesian rats Rattus exulans. These rats are present on both of the island sanctuaries where nesting has occurred. The Kakapo sex ratio is biased in favour of males (34:20) and only 8 of the 19 adult females are known to have laid fertile eggs in the past Io years. Management of all remaining birds is now highly intensive, involving radio-tagging of all individuals, the provision of supplementary food, attempts to manipulate matings, nest surveillance, and protection against rat predation.

\section{Introduction}

The Kakapo Strigops habroptilus is a giant, flightless, nocturnal parrot, and the only representative of a subfamily (Strigopinae) which is endemic to New Zealand. It is one of the world's most endangered birds; classed as "extinct in the wild" in the recent IUCN Red List of threatened animals (IUCN 1996). In both body size and weight it is by far the largest parrot species, with adult males weighing up to $4.0 \mathrm{~kg}$. It is unique amongst parrots in having a "lek" mating system and in exhibiting pronounced sexual dimorphism in body mass; females weigh $30-40 \%$ less than males. It is also believed to have unusually welldeveloped senses of hearing and of smell (Best 1942, J. Hagelin, unpublished data).

Kakapo inhabit forest, scrubland and subalpine habitats, where their diet con- 
sists exclusively of vegetable matter: fruits, seeds, leaves, leaf bases, stems, buds and roots of a wide range of plant species (Gray 1977, Best 1984, Best and Powlesland 1985). Both sexes are solitary and occupy individual home ranges of 15-50 ha (Best and Powlesland 1985, Moorhouse and Powlesland 1991). Adult weights fluctuate widely, both seasonally and annually, by up to $100 \%$ or more. The magnitude of seasonal and periodic weight shifts in Kakapo of both sexes, reflecting the storage and mobilization of fat reserves, appears to be greater than that of any other terrestrial bird (Merton 1994). Breeding occurs in synchrony with the heavy fruiting or "masting" of certain abundant food species, at intervals of 2-5 years (Merton et al. 1984, Powlesland et al. 1992).

Uniquely among parrots, Kakapo are lek breeders (Merton et al. 1984). Adult males in breeding condition congregate in loose associations at traditional sites, typically on ridge tops, where they display both vocally and visually at night to attract females. Each displaying male maintains and defends a "track and bowl system" or "court", consisting of a series of shallow excavated bowls linked by tracks which are kept clear by the bird. Displaying males inflate large thoracic air sacs and produce sequences of loud booming calls from within or near to the bowls within their court. These resonant, low-frequency booming calls may be heard for distances of up to $5 \mathrm{~km}$, and are often alternated with sequences of high-pitched, directional, "chinging" calls. Males may persist in calling activity throughout the hours of darkness (and occasionally also by day), on consecutive nights for up to four months throughout late summer/autumn. The intensity and length of the calling period varies considerably from year to year. In some years male Kakapo display without any females attending the lek, and in other years there is no display activity at all. Kakapo mating has never been directly observed, but is thought to be preceded by an elaborate visual display involving "dancing" by the male. This display has been seen on a number of occasions in response to both humans and inanimate objects within a male's court (Merton et al. 1984, Morris and Smith 1995). It seems that males come into breeding condition more easily and more frequently than females.

Female Kakapo nest in natural cavities at ground level and lay clutches of 14 eggs, which they incubate for about 30 days. Males play no part in nesting, incubation, feeding of females, or in raising of the young. Nestlings remain in the nest for approximately to weeks after hatching, during which time they are left unattended for many hours each night while the female forages for food. Normally only one or two young are raised to independence.

\section{The history of decline}

Kakapo were originally widespread in native forests and scrublands from near sea-level to the subalpine zone throughout New Zealand. Their distribution began to contract after Polynesian settlement (c. $1000 \mathrm{BP}$ ), probably because of hunting by humans and predation by introduced domestic dogs Canis domesticus and Polynesian rats Rattus exulans. Prior to human settlement there were no land mammals in New Zealand, apart from some small bats. The combination of flightlessness, solo parentage, nocturnal behaviour, altricial young, and groundnesting is not found in any other terrestrial bird, and makes the Kakapo exceptionally vulnerable to predation by introduced mammals (Merton 1976, 1994, 


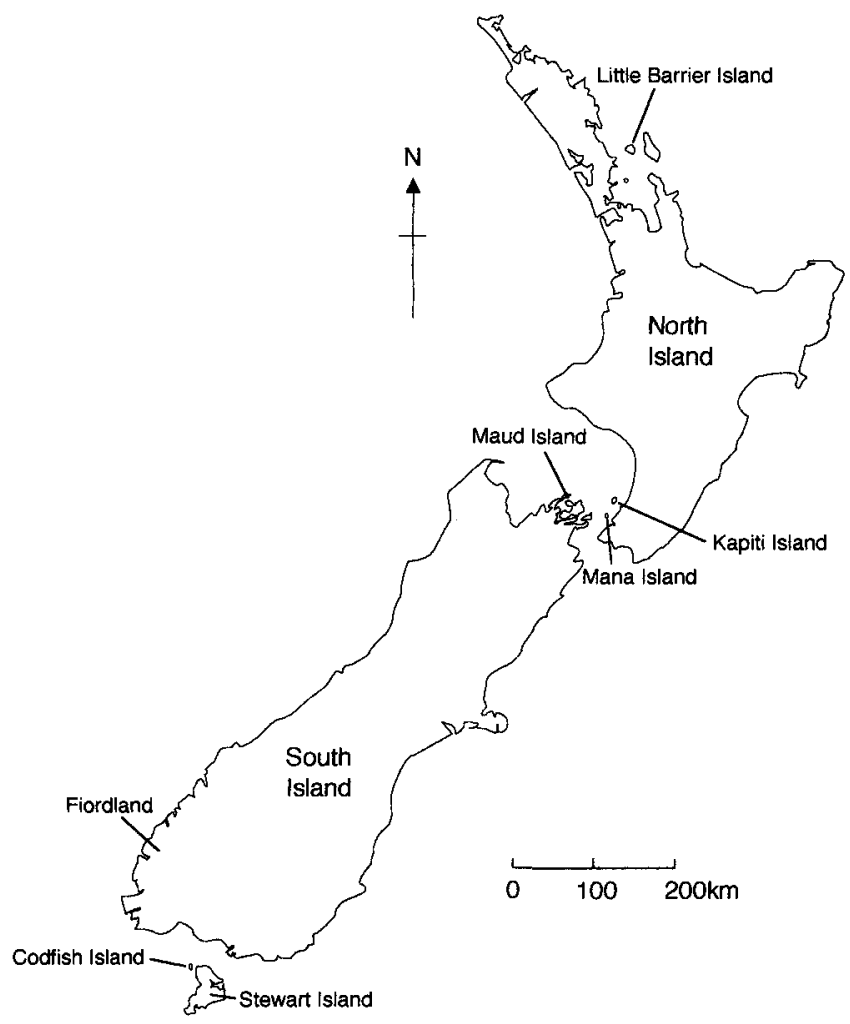

Figure 1. Locations where Kakapo have occurred recently in New Zealand.

Best and Powlesland 1985). Nesting females, eggs and nestlings are particularly at risk.

Although they disappeared from most of their original range in the wake of human colonization, Kakapo remained abundant in Fiordland (in the south-west of New Zealand (Figure 1)), and in some other higher-rainfall and more sparsely inhabited parts of the South Island until the early twentieth century (Williams 1956, Butler 1989).

A decline in the numbers of Kakapo in their last apparent stronghold of Fiordland was first noted at the end of last century, following the introduction and spread of ship rats Rattus rattus and mustelids (Henry 1903, Hill and Hill 1987, Clout and Craig 1995). By the 1950s, Fiordland Kakapo were reduced to a few scattered individuals living in less accessible parts of some remote valleys (Merton 1976, 1987, Butler 1989). When surveys by the New Zealand Wildlife Service in the 1950 and 1960 s revealed how rare the species had become, six birds were captured in an attempt to establish a captive breeding population. All proved to be male and most died after a few months in captivity (Merton 1985, Butler 1989). Captive breeding attempts were abandoned in the 1970s with the discovery that Kakapo are lek breeders (Merton et al. 1984). The focus of Kakapo conservation shifted instead to attempts to establish a population on a predatorfree island (Merton 1976, Butler 1989, Clout and Craig 1995). 
No Kakapo were known to survive in 1974, when a new initiative to find and save the species commenced with intensive searches in Fiordland. Within three years 18 birds had been located there, but all of them proved to be adult males (Merton 1987, Butler 1989). The fragmented, relict Fiordland population apparently declined to extinction by 1989 (Merton, in Rasch 1989, Clout and Craig 1995), dropping in numbers from 15 males in 1977, to 6 in 1981, to 3 or 4 in 1987 and none in 1989. The sole known survivor of the Fiordland population, "Richard Henry", a male of unknown age, was involved in courtship activity and therefore adult, when he was first located in 1975. From subsequent observations of known-age individuals it is apparent that male Kakapo commence courtship activity when five or six years of age. However, because of his physical appearance and other factors, "Richard Henry" is believed to have already been much older than this when removed from Fiordland in 1975 (D. V. Merton, pers. obs.). He is now probably well over 30 years old.

In 1977, when it was evident that the relict population of Kakapo in Fiordland comprised only males (and was therefore functionally extinct), another population was discovered in an area of about 8,ooo ha of fire-modified scrubland and forest in southern Stewart Island (Figure 1). On discovery, this population probably contained 100-200 birds (Powlesland 1989, Clout and Craig 1995). Survival and recovery of the species finally became a realistic goal when the first females seen for more than 70 years (four of them) were found on Stewart Island in 1980.

Mustelids have never colonized Stewart Island, but feral cats Felis catus were introduced by European settlers over a century ago. Soon after Kakapo were discovered on Stewart Island, and research had begun on this population, a severe episode of cat predation on adult birds was recorded. The first indication of this was the detection of Kakapo remains in 6 of 225 cat droppings collected in 1977-1979 (Karl and Best 1982). Subsequently, the corpses of 15 Kakapo killed by cats were found in only 18 months during 1980-1982 (Best and Powlesland 1985). The cat predation rate on adult radio-tagged Kakapo reached $56 \%$ per annum in 1981-1982 (H. A. Best, cited in Moorhouse and Powlesland 1991). Since the Stewart Island Kakapo population obviously could not have withstood this level of predation for the previous century or more, over which time it had presumably coexisted with cats, the most likely explanation of the surge in predation was that one or more individual cats had learned to hunt Kakapo (Butler 1989). With hindsight, this is supported by the fact that predation apparently ceased soon after intensive cat control started in southern Stewart Island in 1982. No cat-predated Kakapo were found after 1983, although some cats continued to use the area inhabited by the remaining birds (Butler 1989). The Stewart Island Kakapo population probably comprised about 140 birds in 1980 , before the main episode of cat predation (Clout and Craig 1995). Within only two years this was apparently halved to around 60 individuals (Figure 2).

\section{Translocation of Kakapo}

The translocation of Kakapo to predator-free islands was first tried as a conservation method by Richard Henry, a visionary early conservationist, who captured and transferred 350-400 Kakapo to Resolution Island in Fiordland in the 1890s and early 1900s (Hill and Hill 1987, Butler 1989). Unfortunately this early attempt 


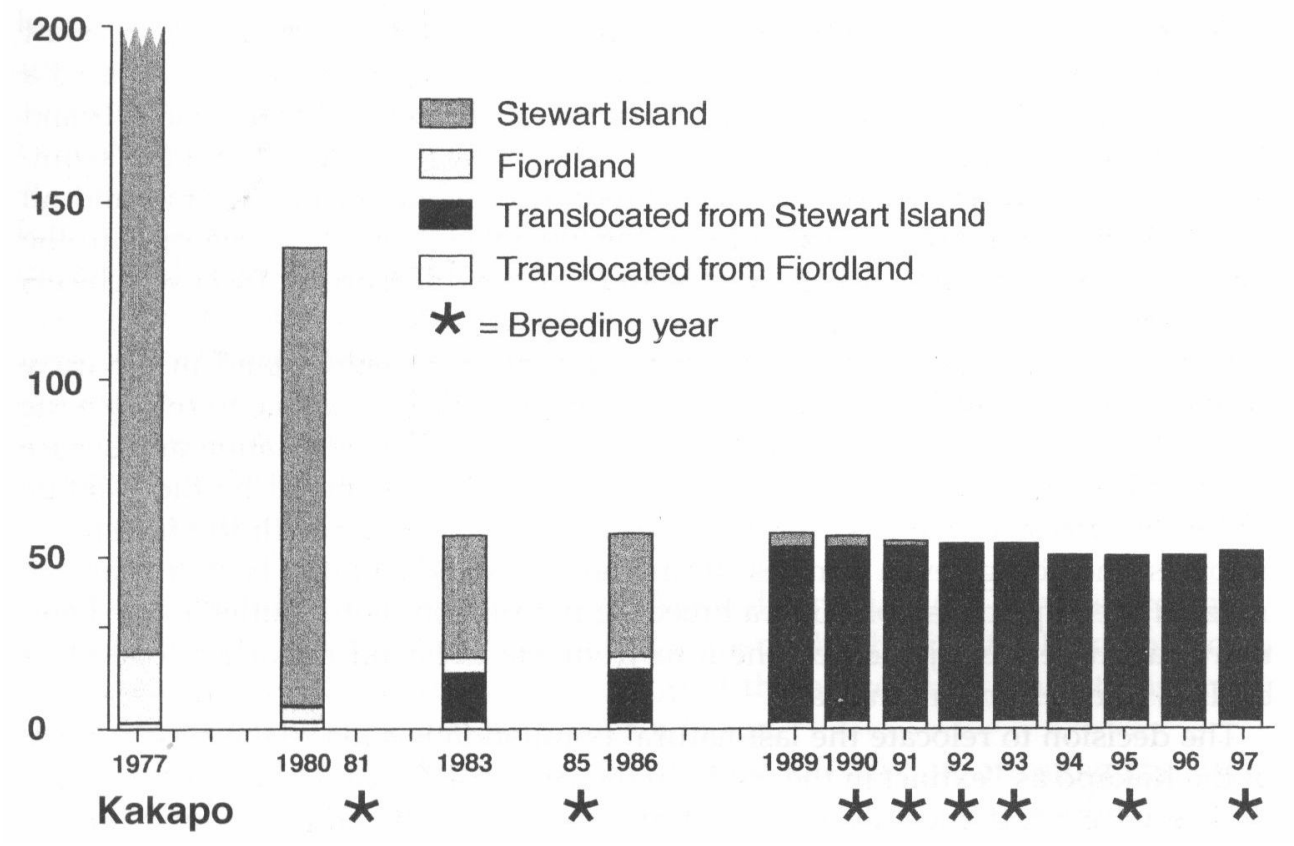

Figure 2. Trends in the estimated world population of Kakapo, 1977-1997.

at Kakapo conservation failed when introduced stoats Mustela erminea colonized Resolution Island soon after 1900. Other early translocation attempts included the release of three Kakapo on to Little Barrier Island in 1903, and a further three on to Kapiti Island in 1912 (Williams 1956, Best and Powlesland 1985). The birds released onto Little Barrier Island were probably killed by cats and those on Kapiti Island were probably all males. The last of the latter was seen in 1936, 24 years after its release; an early indication of the potential longevity of Kakapo.

In 1974 renewed activity was begun to save the Kakapo. It was obvious the species could not be maintained in its natural environment since both mainland New Zealand and Stewart Island had been colonized by introduced predatory mammals. Furthermore, recent attempts to maintain wild-raised Kakapo in captivity had failed. Thus, the use of mammal-free, offshore islands as "safe refuges" or "open aviaries" appeared to be the only practical option remaining. Maud Island, a mammal-free island of 309 ha in the Marlborough Sounds (Figure 1), covered mainly in rank pasture and scrub, with an 18-ha remnant of mature forest, was selected, being one of very few suitable islands free of predatory mammals at that time (Merton 1976).

Two aged Fiordland males were transferred to Maud Island in 1974, another in 1975 and two more in 1981. The first two survived for three years, when one was accidentally killed and the other disappeared. The two transferred in 1981 disappeared shortly after release (Butler 1989). The bird translocated in 1975 was "Richard Henry", which still survives, having been transferred to Little Barrier Island in 1982, and back to Maud Island in 1996. No other Kakapo from mainland New Zealand are known to survive. Following the discovery of females on 
Stewart Island in 1980 three females and one male were transferred from Stewart to Maud in $1980 / 81$. One of the females was in very poor condition and died a few days after being transferred, but the others survived. Although Maud Island is usually free of mammals, it is only $900 \mathrm{~m}$ offshore and thus within the swimming range of stoats. In 1982 stoats temporarily invaded Maud Island and all four Kakapo there (two males and two females) were rapidly transferred to the larger, heavily forested Little Barrier Island ( 3083 ha) (Figure 1), from which cats had recently been eradicated (Veitch and Bell 1990).

Following the episode of severe cat predation on Stewart Island in the early 1980s, a decision was made by the New Zealand Wildlife Service to relocate the Stewart Island population to avoid further losses from cat predation and secure the remnant stock. This programme, which has been continued by the Wildlife Service's successor, the Department of Conservation, began with the transfer of 18 birds (including seven females) from Stewart Island to Little Barrier Island in 1982, in the hope of establishing a breeding population there (Butler 1989). Later that year these were joined by the four from Maud Island making a total of 22 birds, 9 females and 13 males.

The decision to relocate the last natural population has led to the classification of the Kakapo as "extinct in the wild" in the current IUCN Red List (IUCN 1996). Between 1987 and 1997 all remaining 38 Kakapo which could be found on Stewart Island were translocated. Most of them (20 males, 11 females) were released on Codfish Island (Figure 1), a forested 1,396-ha island off the north-western coast of Stewart Island, which during the 1980s had been cleared of all predatory Weka Gallirallus australis and Australian brushtail possums Trichosurus vulpecula (Veitch and Bell 1990). During the period 1989-1991 six Stewart Island birds (four males, two females) were released on Maud Island, which had been cleared of stoats after the 1982 invasion. The last two males were taken from Stewart Island in 1992 and released on Mana Island (Figure 1), a 217-ha mammal-free island covered mainly in rank pasture and scrub, from which house mice Mus musculus were eradicated in 1989 .

\section{Survival of translocated Kakapo}

The survival rate of the 6o Kakapo translocated from Stewart Island between 1980 and 1992 has been high, despite the fact that all but three (one male, two females) were adults of unknown age when transferred. At least 47 of the original $60(78 \%)$ still survive. Forty-four of these are now at least 20 years old, and most are likely to be considerably older than this. All known Kakapo are now radio-tagged, so deaths can be readily detected.

On Little Barrier Island, 16 of the 22 birds released in 1982 are known to have survived to 1997. Two birds are missing (presumed dead) and four are known to have died. Three of these were males, two of which died as a result of fights with other male Kakapo (in successive summers) for possession of a particular court or track and bowl system. Clout and Craig (1995) calculated that the survival rate of translocated Kakapo on Little Barrier averaged between $97 \%$ and $98.5 \%$ per annum over the 12 years from 1982 to 1994 . The overall survival rate for the 15 years since 1982 now averages $98.2 \%$ per annum.

On Codfish Island the survival rate of translocated Kakapo has been similarly 
high, exceeding $98 \%$ per annum. Of the original 30 birds released there since 198726 are known to have survived to 1997, including all 10 females.

The early record of Maud Island for survival of translocated Kakapo was poor. Four of the five Fiordland males released there between 1974 and 1981 died within three years, and one underweight female from a group of four Stewart Island birds also died soon after release in 1981. However, all five of the birds released to free-range on Maud Island between 1989 and 1991 have survived, despite a reinvasion by stoats, which were again present for over two years from 1991 before being eradicated. The high mortality of Fiordland birds transferred to Maud is likely to have been related to the extreme old age of these individuals. During this same period free-living birds remaining in Fiordland were in steep decline. Not one of the 15 birds present in Fiordland in 1977 is known to have survived beyond 1987, and the species is now believed to be extinct there (Merton, in Rasch 1989).

Both of the adult males released on Mana Island in 1992 have since died, suggesting that this island may currently be unsuitable habitat for Kakapo. However, the extremely light weights $(c .1 .5 \mathrm{~kg}$ ) of these two birds when transferred from Stewart Island may also have been a factor.

The translocation of Kakapo has been highly effective in arresting the catastrophic rate of decline in numbers which was occurring in the last known natural populations in the early 1980s (Clout and Craig 1995), but has not yet reversed it. There are $\sim 15 \%$ fewer Kakapo alive now than there were in 1982, when translocation of the species commenced (Figure 2).

The overall survival statistics for translocated Kakapo suggest that the mortality rate has been higher among males than females. Known deaths in the original 6o birds translocated from Stewart Island to free-range on offshore islands since 1980 include five males and two females. Missing birds (presumed dead) also include five males and two females. Stewart Island birds translocated since 1980 originally consisted of 38 males and 22 females. Known survivors of this group now consist of 28 males and 18 females. The higher mortality of translocated males reverses the previous trend of higher female mortality in the presence of stoats or cats, as suggested by the biased sex ratio. Some of the recent male mortality was due to fighting at lek sites; it is also possible that there were more very old individuals among transferred males and that males adapt less easily than females to novel environments.

\section{Breeding of translocated Kakapo}

Although adult survival has been remarkably high, the productivity of translocated Kakapo has been disappointingly low (Figure 3). On Little Barrier Island there were no known breeding attempts for seven years after the transfer of Kakapo in 1982 (Powlesland et al. 1992). On Codfish Island there have been two breeding seasons since birds were first released there in 1987, and on Maud Island there have been no breeding attempts at all by the two females introduced in 1991 .

Powlesland et al. (1992) discovered that Kakapo on Stewart Island bred only when protein-rich foods, especially the seeds of mast-fruiting podocarp trees Dacrydium spp., were abundant. Following this revelation, a proposal was made 


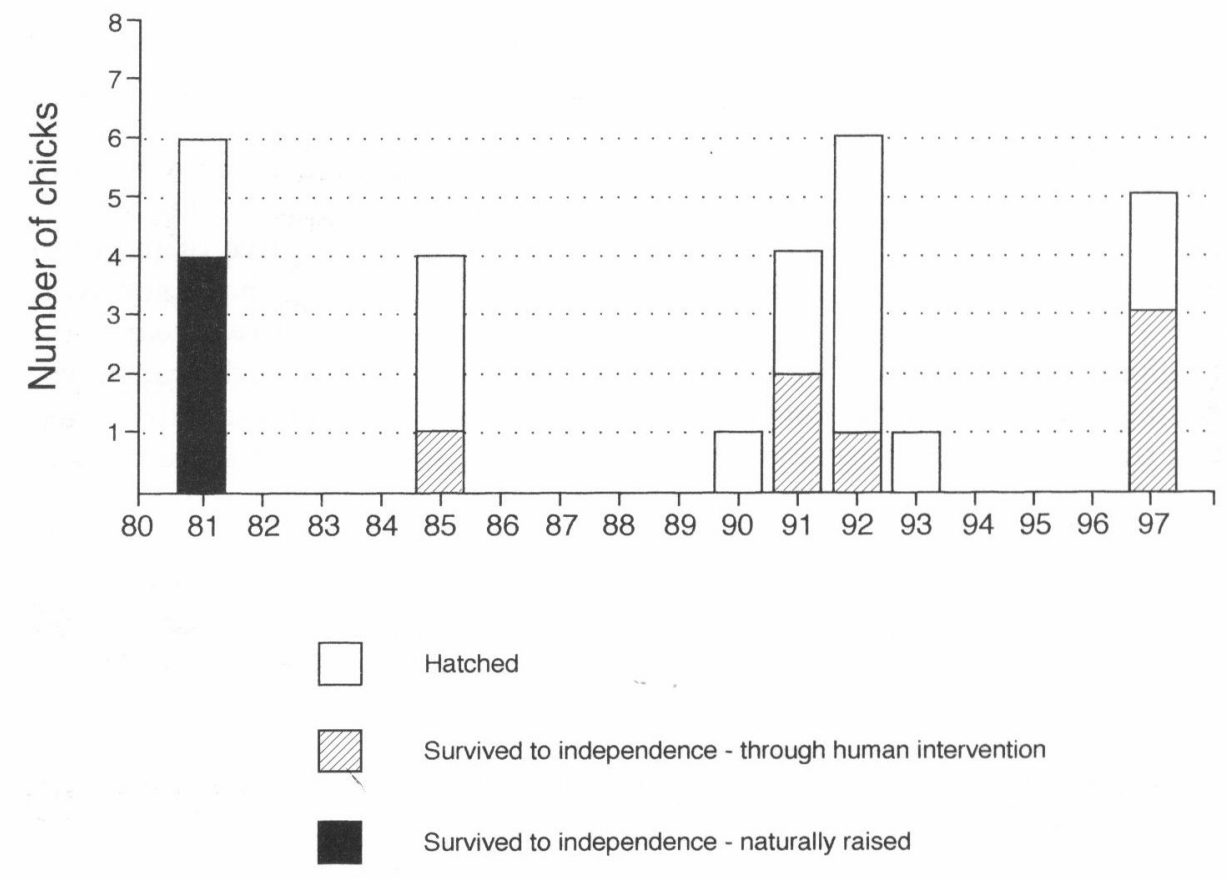

Figure 3. Kakapo chicks known to have hatched, 1980-1997.

by Powlesland (1989) and others to test the effect of providing supplementary foods on Kakapo breeding. In 1989, nuts, apples and sweet potatoes were therefore provided at artificial feeding stations to free-living Kakapo on Little Barrier Island (James et al. 1991). The initial response was highly promising; the frequency and intensity of male booming increased markedly, and nesting occurred in four of the six years after supplementary food was first provided (Greene 1993; Clout and Craig 1995). However, the end result was the recruitment of only two young males, one each from 2 of the 10 nests detected. This low productivity was a combined result of a low proportion of females nesting, a high proportion of infertile eggs $(\sim 40 \%)$, and the early death or disappearance of nestlings from three nests. Two, and in one instance four, of the up to seven females on Little Barrier Island participated in the breeding seasons there. In the most recent breeding season on this island (1995) only two of the four supplementary-fed females nested and both laid infertile eggs, despite having laid fertile clutches in previous seasons. On Maud Island supplementary food has been provided to Kakapo since 1991, but there have been no breeding attempts by the two females there over the past six years.

On Codfish Island, translocated birds were not initially provided with supplementary food. In 1992 at least four females bred in synchrony with the heavy fruiting of rimu Dacrydium cupressinum trees on the island, but the fruit crop failed and chicks starved (Higham 1992, Merton 1994). Because of starvation and probable predation by Polynesian rats, no chick was raised on the island. However, of the six nestlings known to have hatched, three were rescued for handraising and one of these (a female) survived. This bird was the progeny of one 


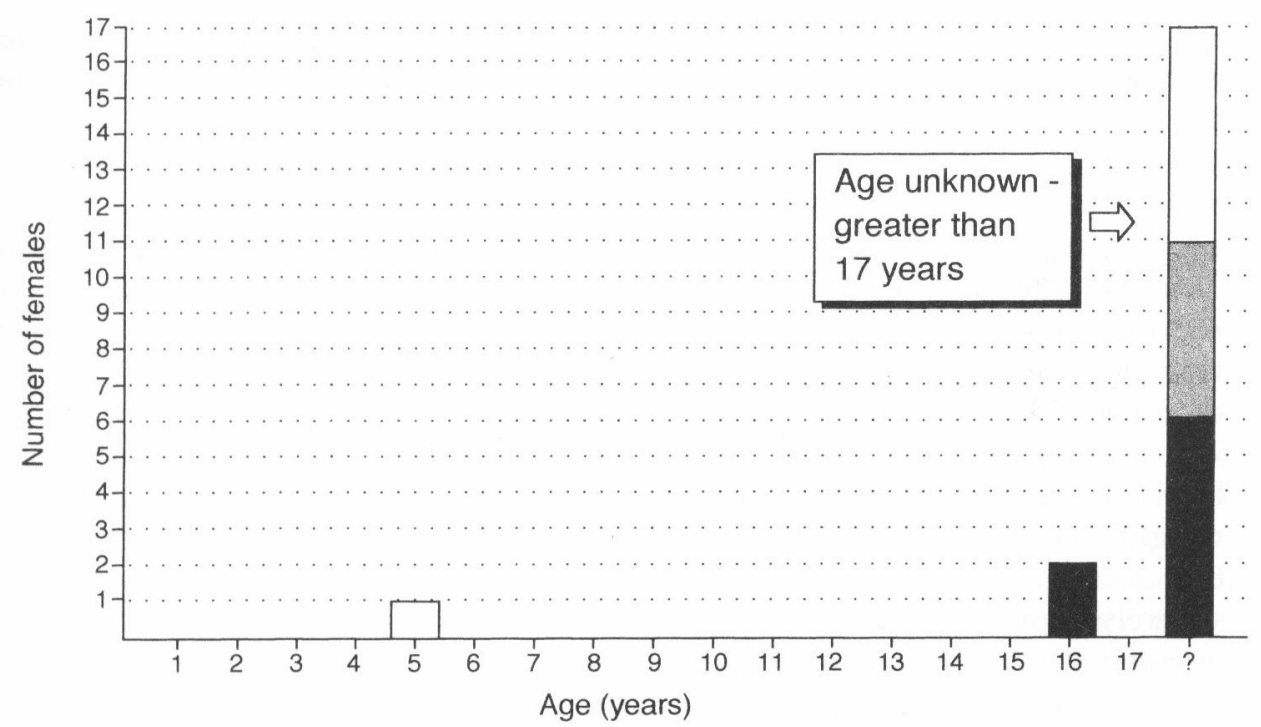

No known egg production

Infertile eggs only

Fertile eggs produced

Figure 4. Age distribution of surviving female Kakapo in 1997 and egg production (19871997 ) in relation to age.

of only three known-age females, an 11-year-old apparently breeding for the first time. The surviving chick had been found starving in the nest and was removed (together with its starving sibling). It was placed in the nest of another female Kakapo on Codfish Island which had previously raised young successfully, but was incubating a clutch of infertile eggs. The nestling of approximately two weeks old was immediately accepted and fed by this experienced female, despite the rimu fruit crop failure. The chick made normal weight gains for three weeks before beginning to lose weight again. It was then taken into captivity and successfully hand-raised. After five years in captivity on Maud Island it was returned to free-range on Codfish Island in June 1997. This bird remains the only female Kakapo to have been recruited to the entire population since 1981 (Figure 4).

Following the experience of the 1992 breeding season, 7 of the 10 female Kakapo then on Codfish Island were brought into the supplementary feeding programme in an attempt to increase breeding frequency as well as to avoid further chick starvation. However, the year-round provision of supplementary food to most of the birds on Codfish Island did not produce a breeding response. The next breeding season (involving both fed and non-fed females) was five years later, in 1997. Once again it was in synchrony with heavy fruiting of rimu trees, the first such event since 1992.

Eight of the ten Codfish Island females are believed to have visited the lek during February 1997 and to have mated. Within 18 days of mating, six of these birds had nested. The other two apparently did not nest. The six females laid a 
total of 12 eggs of which 7 were fertile. All eggs were left with the females. There were two early dead embryos, but five eggs hatched. One of the five nestlings died immediately after hatching.

As in the 1992 season, the 1997 crop of rimu fruit failed on Codfish Island; most fruit did not ripen and aborted and it was therefore impossible for nonsupplementary-fed females to find sufficient food to raise their young. The chick from the only non-supplementary-fed female to produce young in 1997 was consequently removed for hand-raising in captivity, since at $\mathbf{1 2}$ days of age the chick was seriously underweight. This chick was hand-fed for nine days, during which time its weight increased. It was then fostered to a supplementary-fed female with an infertile clutch, which readily accepted and fed the three-week-old chick. However, even with some direct supplementary hand-feeding in the wild, its weight gains after a further nine days were unsatisfactory. The nestling was therefore again removed from the nest and raised by hand. It was, however, severely stunted and died at fledging age ( $\sim 11$ weeks). One other nestling developed respiratory problems during a prolonged cold, wet spell of weather and began to lose weight. This chick was also removed from the wild for medical treatment and was hand-raised. It responded well and was returned to Codfish Island in early July 1997 for release to free-range. The other two surviving nestlings were left with their supplementary-fed mothers and fledged successfully. All three of the young raised in 1997 were male.

Many of the recent losses of nestlings on both Little Barrier and Codfish Islands have been attributed to predation by Polynesian rats (B. M. Fitzgerald, unpublished data 1992, D. V. Merton, pers. obs.), with the implication that the translocated Kakapo are not in fact on "predator-free" islands. They are exposed not only to periodic invasion by stoats on Maud Island, but also to resident, often high-density populations of Polynesian rats on Little Barrier and Codfish Islands.

The Kakapo is in an extreme reproductive crisis. It has an ageing population and a critical need for the recruitment of young females to the breeding population. Its breeding cycles are ponderously slow - amongst the slowest of all birds and productivity is alarmingly low. A unique combination of physiological and behavioural traits means that eggs and nestlings are exceedingly vulnerable to predation by rats, which are present on two of the three islands to which the species is now confined. Furthermore, the sex ratio is heavily biased against females, although less so than in the recent past because of differential male mortality following translocation. Only 8 of 19 adult females are known to have laid fertile eggs in the past 10 years (Figure 4) and the most recent clutches by two of these individuals (on Little Barrier Island) were infertile. All known females are radio-tagged and carefully monitored in the breeding season, so that it is extremely unlikely that any have nested without being detected. Since 17 of the 20 females are of unknown age - hatched during or before the 1970 - it is possible that many, if not most, of the female population may already be too old to lay fertile eggs (Figure 4 ).

\section{The Kakapo recovery plan (1996-2005) and recent management actions}

The first recovery plan for the Kakapo (Powlesland 1989) described the status of the Kakapo population and identified management and research goals and prior- 
ities for the five years to 1994. Major foci over this period were the location and transfer of remaining birds from Stewart Island and the introduction and refinement of monitoring and supplementary feeding programmes.

At the end of 1994 the Kakapo recovery programme was reviewed by an international group of experts (Imboden et al. 1995). The review recommended substantial restructuring, including some new research and management directions. In the light of these recommendations the Department of Conservation consolidated the administrative structure into a centrally based National Kakapo Team (NKT) to integrate research and management that had previously been run from within the Department's regional structure. The activities of the NKT are scrutinized by an advisory committee, the Kakapo Scientific and Technical Advisory Committee (KTSAC), comprising independent senior scientists and technical experts. It is through this committee that the national team of managers, scientists, and programme officers on the Kakapo islands develop work plans and priorities. One of the first tasks was the preparation of a new recovery plan, based on the review by Imboden et al. (1995). The content of this was debated at a 1995 workshop. The resultant new Kakapo recovery plan for the period 19962005 was published by the Department of Conservation in 1996.

The stated vision for the Kakapo recovery programme is ultimately "to establish at least one viable, self-sustaining, unmanaged population of Kakapo as a functional component of the ecosystem in a protected habitat, and to establish two or more other populations which may require ongoing management". The new recovery plan covers a 10-year period, recognizing that the Kakapo is one of the slowest-breeding birds on earth and that recovery will inevitably be slow. The major foci are to maintain all surviving birds in a healthy state and to maximize production and survival of chicks so that they can be recruited into free-living breeding populations. Particular priority is being given to research aimed at increasing breeding frequency.

Maximizing egg and chick survival has as its major thrusts the protection of nests on Little Barrier and Codfish Islands from predation by rats, the support of breeding females to ensure adequate nutrition for chicks and the effective monitoring of all nests. These aims are to be achieved through controlling rats near all nests, provision of supplementary foods to all females and the monitoring of all nests by remote, infra-red video systems. Where necessary, eggs and nestlings will be removed for artificial hatching and hand-rearing. Ultimately, it is proposed to remove the risk of rat predation altogether, through eradication of Polynesian rats from both Little Barrier and Codfish Islands. Although both of these islands are large, a successful rat eradication campaign was recently mounted against both Polynesian and Norway rats Rattus norvegicus on Kapiti Island (c. 2,00o ha), which is of similar size to Little Barrier and Codfish Islands. If rat eradication were to proceed on Little Barrier or Codfish Island it would involve the temporary removal of all Kakapo so as to avoid exposing the birds to poison baits. Capturing the birds would be feasible since all are radio-tagged, but a suitable temporary island home would be needed. The search for, and preparation of, other safe islands for Kakapo is therefore important.

Maintaining and increasing the breeding life of surviving Kakapo is vital, given concerns about the biased age structure and apparent low number of fertile females. The first priority is to minimize adult mortality. The next is to investi- 
gate ways of extending breeding life, including possible refinements to the supplementary diet and the potential for invasive hormone therapy. Known or likely sources of manageable risks are conflict between males at lek sites (especially on Little Barrier, where the island's confined summit area is a much-coveted display site), and the possibility of stoats recolonizing Maud Island. Any stoat reaching the island would pose an unacceptable risk to breeding females in particular.

In 1996, two dominant males, whose fertility was in question, were transferred from Little Barrier Island to an island off the coast of Stewart Island, to enable potentially fertile males to take over their prime display sites. Whilst these two males held key sites on Little Barrier Island, two previously fertile females which mated with them laid infertile clutches, raising doubts about the fertility of these particular males. Their removal provides a means of testing this hypothesis. It also provides a means of determining the suitability of the new island as a temporary refuge for Kakapo during planned rat eradication on the other islands.

Identifying ways of increasing breeding frequency will involve further research into both natural and supplemental diets. It will include review of the relationship between plant phenology and Kakapo breeding, diet analysis from droppings and research into plant nutrient and hormone levels and other environmental factors which might serve as breeding cues in Kakapo. It will also involve refinement of the supplementary diet and feeding regimes. Of the 20 female Kakapo 17 now regularly receive supplementary foods, but the regime of providing similar amounts of food throughout the year did not succeed in stimulating breeding on Codfish Island. The 1997 breeding season was evidently in response to a natural flush of food provided by heavy fruiting of rimu trees. This suggests that a pulsing of supplementary food may be a more successful approach. Although the continous feeding regime failed to stimulate breeding on Codfish Island, supplementary food is apparently necessary for successful chick-raising on this island. During the two breeding seasons on Codfish Island only supplementary-fed females have proved capable of raising young. A concerted effort is therefore being made to train the non-fed birds on Codfish Island to recognize supplementary foods and to feed from rat-proof hoppers.

Determining where potential productivity is being lost entails critical investigation into the causes of egg and chick mortality and adult infertility. Methods are being developed to assess the fertility of individuals, including identification of birds involved in matings through microsatellite DNA sequencing and the collection of sperm from lekking males. Development of the capability to manipulate matings to ensure that fertile birds mate with one another, as well as to facilitate maintenance of genetic diversity, is seen as an important long-term goal.

Maintenance of genetic diversity has involved the collection of blood, tissue or feather samples from every known Kakapo and the development of a DNA database for the species. This information will be used in the management of surviving breeding birds to retain as much genetic diversity as possible through manipulation of matings. A prime consideration will be the preservation of the genetic material represented by "Richard Henry", the sole remaining Kakapo from the New Zealand mainland. If effective and safe sperm collection and storage techniques can be devised, attempts will be made to collect and store sperm from this male in particular for possible use in any future artificial insemination programme. "Richard Henry" had not attended the lek on Little Barrier Island for 
Table 1. Kakapo known to survive, August 1997

\begin{tabular}{llllllr}
\hline & \multicolumn{2}{c}{ Female } & & \multicolumn{2}{c}{ Male } & Totals \\
\cline { 2 - 3 } & Subadult & Aduit & & Subadult & Adult & \\
\hline Codfish Island & 1 & 13 & & 3 & 16 & 33 \\
Maud Island & 0 & 3 & & 0 & 4 & 7 \\
Little Barrier Island & 0 & 3 & & 0 & 9 & 12 \\
Holding Island & 0 & 0 & & 0 & 2 & 2 \\
Totals & 1 & 19 & & & 31 & 54 \\
\hline
\end{tabular}

several years, so there was little prospect of him contributing genetically there. A decision was therefore made to transfer him back to Maud Island in 1996 in the hope that proximity to the lek on that smaller island might enhance his contact with other birds in breeding condition. He displayed vigorously at the Maud Island lek over the summer of 1997-1998.

At the same time, a non-supplementary-fed and unproductive female from Little Barrier, which had been living distantly from the lek there (and possibly out of earshot) was transferred to Maud Island in the hope of stimulating breeding activity in a more manageable situation.

For similar reasons, two females of unknown age from Little Barrier Island were relocated to Codfish Island in June 1997. Both had free-ranged on Little Barrier Island since 1982 and had received food supplementation since 1989 . One is not known to have attempted to breed at all during this 15 -year period. The other, without visiting the lek, produced two infertile, single-egg clutches in successive seasons immediately after the commencement of supplementary feeding. No abundant, mast-fruiting plant that might serve as a natural stimulus to breeding appears to exist on Little Barrier Island. Relocation to Codfish Island, where Kakapo have twice bred in synchrony with infrequent heavy fruiting of rimu, might offer the best chance to facilitate breeding by these two females, if in fact they are still capable of producing fertile eggs. Codfish Island offers a further advantage in that the lek there is much lower in altitude and significantly closer to most female home-ranges than that of Little Barrier Island. For these reasons, the solitary, hand-raised, captive female from Maud Island (aged five years) was also released to free-range on Codfish Island in July 1997.

Finally, in June 1997 a "new" adult female Kakapo of unknown age was captured in the south of Stewart Island and released on Codfish Island, bringing the total number of females which are known to exist to 20, of which 14 are now on Codfish Island. The possibility of other isolated individuals persisting in the vast scrublands of southern Stewart Island cannot be discounted, making further searches there a priority.

\section{Conclusions}

Fifty-four Kakapo are currently known to exist (Table 1). As a result of the recent repositioning of birds between islands, Little Barrier Island now has 12 Kakapo ( 9 males and 3 females), Maud Island has 7 (4 males and 3 females), Codfish Island has 33 (19 males and 14 females), and a small island off southern Stewart 
Island temporarily holds 2 males. All 54 birds are banded, equipped with radiotransmitters, and individually named. Conservation of the Kakapo has for the past eight years entailed "close order management", intensive management at the individual rather than population level. The potential contribution of each individual, in terms of both productivity and as research subjects, is now vital to the species's survival and recovery.

The Kakapo recovery programme faces a daunting array of physical and biological challenges, but an intensive conservation programme is now underway. The main reasons for hope are the longevity of Kakapo, and their adaptability to new environments and foods. There are obviously some major difficulties in conducting a scientifically-based programme with such a small number of individuals. Treatments and controls cannot be designed with sufficiently large sample sizes and there are not enough individuals - or years - to be able to conduct all of the desired trials. Surrogate species are of limited scientific usefulness because no other bird closely resembles the Kakapo, with its unique combination of behavioural and physiological traits. Although every attempt is made to use a scientific approach, conservation decisions typically have to be made with inadequate information. Often the option chosen has to be the one which promises a better than even chance of succeeding, rather than waiting for the level of probability traditionally accepted for statistical significance.

The Kakapo has individual longevity and robustness on its side. However, its ageing population, heavily biased sex ratio, infrequent breeding, exceedingly low natural productivity, high levels of infertility, and the vulnerability of its young to food shortage and rat predation, means that the species is incapable of rapid recovery. Despite these odds, the species still exists, and an effective recovery programme is underway. It is to be hoped that the next decade will see this unique bird firmly on the path to recovery.

\section{Note added in proof}

In February 1998 a female Kakapo on Maud Island nested in an exotic pine plantation and laid three fertile eggs. All of these hatched and the chicks (one female, two males) were raised to independence. The nesting female concerned had been transferred in 1996 from Little Barrier Island, where she had lived (evidently without breeding) for 14 years.

This event is significant for several reasons. Firstly, it adds another breeding female to the world population-nine of nineteen adult females are now known to have laid fertile eggs during the past ten years. Secondly, the three young birds carry genes from the relict Fiordland population because their father is "Richard Henry", the last known Kakapo from the New Zealand mainland. Thirdly, it proves that Maud Island is a suitable place for Kakapo breeding. Finally, the new juvenile female is only the second Kakapo of this sex to have survived to independence since 1981. The world Kakapo population now stands at 57 .

Following this successful breeding, and a subsequent review of management actions, it was decided to remove all remaining Kakapo from Little Barrier Island. The three females have now been transferred from there to Maud Ialand; the males to other islands. Eradication of Polynesian rats from Codfish Island is scheduled for July 1998, which has entailed the temporary removal of all Kakapo from there to a "holding island" whilst the rat poisoning takes place. 


\section{Acknowledgements}

We thank Paul Jansen, Graeme Elliott and other members of the National Kakapo Team of the New Zealand Department of Conservation for the provision of recent information on Kakapo, and for their helpful comments on earlier drafts. We also thank Peter Jones of the University of Edinburgh for his earlier encouragement and constructive comments.

\section{References}

Best, E. (1942) Forest lore of the Maori. Dominion Mus. Bull. 14: 211-216.

Best, H. A. (1984) The foods of kakapo on Stewart Island as determined from their feeding sign. NZ. J. Ecol 7: 71-83.

Best, H. A. and Powlesland, R. G. (1985) Kakapo. Dunedin: J. McIndoe and New Zealand Wildlife Service.

Butler, D. (1989) Quest for the Kakapo. Auckland: Heinemann Reed.

Clout, M. N. and Craig, J. L. (1995) The conservation of critically endangered flightless birds in New Zealand. Ibis 137: S181-S190.

Department of Conservation (1996) Kakapo Recovery Plan 1996-2005. Threatened Species Recovery Plan No. 21. Wellington: Department of Conservation.

Gray, R. S. (1977) The kakapo (Strigops habroptilus, Gray, 1847) its food, feeding and habitat in Fiordland and Maud Island. MSc thesis, Massey University.

Greene, T. C. (1993) Kakapo breeding activity on Little Barrier Island October 1992-April 1993. Auckland: Department of Conservation. Auckland. Conservancy Tech. Rep. Series no. 8.

Henry, R. (1903) The habits of the flightless birds of New Zealand; with notes on other New Zealand birds. Wellington: Government Printer.

Higham, T. (1992) The Kakapo of Codfish Island. NZ Geogr. 15: 30-38.

Hill, S. and Hill, J. (1987) Richard Henry of Resolution Island: a biography. Dunedin: J. McIndoe and New Zealand Wildlife Service.

Imboden, C., Jones, P. and Atkinson, I. A. E. (1995) Review of the Kakapo Recovery Programme. Report for the New Zealand Department of Conservation. Unpublished report (January 1995). Wellington: Department of Conservation.

IUCN (1996) 1996 IUCN red list of threatened animals. Gland, Switzerland: IUCN.

James, K. A. C., Waghorn, G. C., Powlesland, R. G. and Lloyd, B. D. (1991) Supplementary feeding of Kakapo on Little Barrier Island. Proc. Nutrit. Soc. NZ 16: 93-102.

Karl, B. J. and Best, H. A. (1982) Feral cats on Stewart Island: their foods and their effects on Kakapo. NZ J. Zool. 9: 287-294.

Merton, D. V. (1976) Conservation of the kakapo : a progress report. Proceedings of Seminar on Science in National Parks, August 1976. Wellington: National Parks Authority.

Merton, D. V. (1985) Kakapo. Pp. 242-243 in C. J. R. Robertson, ed. Complete book of New Zealand birds. Sydney: Readers Digest.

Merton, D. V. (1987) Epilogue. Pp. 318-323 in S. Hill and J. Hill, Richard Henry of Resolution Island: a biography. Dunedin: J. McIndoe and New Zealand Wildlife Service.

Merton, D. V. (1994) Saving the kakapo: a case of intervention, or extinction. Pp. 145-155 in Proceedings of III International Parrot Convention.

Merton, D. V., Morris, R. D. and Atkinson, I. A. E. (1984) Lek behaviour in a parrot: the Kakapo Strigops habroptilus of New Zealand. Ibis 126: 277-283.

Morris, R. and Smith, H. (1995) Wild South: saving New Zealands's endangered birds, second edition. New Zealand: TVNZ and Random House NZ.

Moorhouse, R. J. and Powlesland, R. G. (1991) Aspects of the ecology of Kakapo Strigops habroptilus liberated on Little Barrier Island (Hauturu), New Zealand. Biol. Conserv. 56: $349-365$. 
Powlesland, R. G. (1989) Recovery plan for Kakapo, 1989-1994. Wellington: Department of Conservation.

Powlesland, R. G., Lloyd, B. D., Best, H. A. and Merton, D. V. (1992) Breeding biology of the Kakapo Strigops habroptilus on Stewart Island, New Zealand. Ibis 134: 361-373.

Rasch, G. (1989) Proceedings of the workshop on conservation of kakapo: with recommendations for 1989-94 kakapo recovery plan. Wellington: Department of Conservation.

Veitch, C. R. and Bell, B. D. (1990) Eradication of introduced mammals from the islands of New Zealand. Pp. 137-146 in D. R. Towns, C. H. Daugherty and I. A. E. Atkinson, eds. Ecological restoration of New Zealand islands. Wellington: Department of Conservation (Conservation Sciences Publ. 2).

Williams, G. R. (1956) The Kakapo (Strigops habroptilus, Gray). A review and re-appraisal of a near-extinct species. Notornis 7: 29-56.

\section{MICK CLOUT}

Centre for Conservation Biology, School of Biological Sciences, The University of Auckland, Private Bag 92019, Auckland, New Zealand.

\section{DOIN MERTON}

Kakapo Management Group, Biodiversity Recovery Unit, STIS, Department of Conservation, PO Box 10 420, Wellington, New Zealand. 